Journal of Clinical Investigation
Vol. $42, \mathrm{No} 4,1963$

\title{
THE "INDUCTION" OF DIHYDROFOLIC REDUCTASE ACTIVITY IN LEUKOCYTES AND ERYTHROCYTES OF PATIENTS TREATED WITH AMETHOPTERIN *
}

\author{
By J. R. BERTINO,† D. M. DONOHUE, B. SIMMONS, B. W. GABRIO, R. SILBER, \\ AND F. M. HUENNEKENS §
}

(From the Departments of Medicine and Biochemistry, University of Washington and King County Blood Bank, Seattle, Wash.)

(Submitted for publication October 8, 1962; accepted December 6, 1962)

Dihydrofolic reductase $(2,3)$ catalyzes the TPNH-dependent reduction of dihydrofolate to tetrahydrofolate-dihydrofolate $+\mathrm{TPNH}+\mathrm{H}^{+} \rightleftharpoons$ tetrahydrofolate $+\mathrm{TPN}^{+}-($reaction 1$)$ and, to a lesser extent, the reduction of folate to tetrahydro- folate. The enzyme also participates in the synthesis of thymidylate (4), a key constituent of DNA, via the following cyclic series of reactions in which the " $\mathrm{C}_{1}$ " unit may be donated by serine or other metabolites containing a potential onecarbon unit (5).

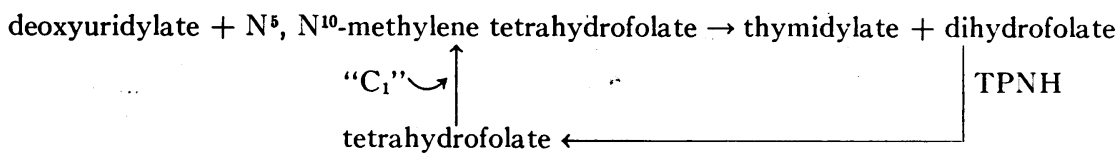

Since the observation that dihydrofolic reductase is powerfully inhibited by the folic acid antagonists aminopterin ${ }^{1}$ and amethopterin ${ }^{2}(6-10)$, the development of resistance to these agents has been studied in bacteria (11-14), cultured cells $(15,16), \mathrm{L}-1210$ leukemic mice $(17)$, and human leukemia $(1,18,19)$. In each of these instances, exposure of the system to the folic acid antagonists resulted in an increased level of dihydrofolic reductase, suggesting that these events were associated with resistance.

In a previous study (19), an increased level of dihydrofolic reductase after amethopterin was

* This work was supported in part by U. S. Public Health Service grants CYP-4252 and OG-13, and by American Cancer Society grant P-203. Part of this work was presented elsewhere in preliminary form (1).

$\dagger$ Postdoctoral Fellow of the National Heart Institute, U. S. Public Health Service. Present address: Department of Pharmacology, Yale University School of Medicine, New Haven, Conn.

$\ddagger$ Special Fellow of the National Cancer Institute, U. S. Public Health Service. Present address: Department of Medicine, New York University, N. Y., N. Y.

$\S$ Present address: Division of Biochemistry, Scripps Clinic and Research Foundation, La Jolla, Calif.

${ }^{1} N$ - $\{p$-[ (2,4-Diamino-6-pteridylmethyl) amino]benzoyl $\}$ glutamic acid.

$2 N$-\{p-[ (2,4-Diamino-6-pteridylmethyl ) methylamino] benzoyl $\}$-glutamic acid. noted in the leukocytes from patients with leukemia. The present investigation extends these observations and includes the effect of amethopterin treatment on the level of dihydrofolic reductase in leukocytes and erythrocytes of nonleukemic patients. A possible mechanism is proposed to account for the increased enzyme level in normal and leukemic cells exposed to amethopterin.

\section{MATERIALS AND METHODS}

Chemicals. ATP, ${ }^{3}$ TPN, ${ }^{3}$ TPNH, ${ }^{3}$ DPN, ${ }^{3}$ DPNH, ${ }^{3}$ folic acid, ${ }^{4}$ and protamine sulfate 4 were obtained from manufacturers. DEAE-cellulose ${ }^{5}$ was prepared according to the method of Sober, Gotter, Wyckoff, and Peterson (20). Dihydrofolic acid was prepared according to the procedure of Futterman (21) as modified by Blakley (22).

Methods. Venous blood was collected in heparin from patients at the King County Hospital or the Clinical Research Center of the University of Washington Hospital. Leukocytes were isolated from blood and lysed by high speed homogenization by procedures described elsewhere (23). Erythrocytes were recovered from blood by centrifugation, washed twice with $0.15 \mathrm{M} \mathrm{KCl}$, and lysed by treatment with 4 volumes of $0.005 \mathrm{M}$ potassium phosphate buffer at $\mathrm{pH} 8.0$ (24). Protein concentration

\footnotetext{
${ }^{3}$ Sigma Chemical Company, St. Louis, Mo.

${ }^{4}$ Nutritional Biochemicals Corporation, Cleveland, Ohio.

5 Eastman Organic Chemicals, Rochester, N. Y.
} 
was determined by the biuret method in crude extracts, or by absorbancy at $280 \mathrm{~m} \mu$ in purified preparations. Crystalline bovine serum albumin was used as the standard for both methods. Hemoglobin was determined spectrophotometrically at $540 \mathrm{~m} \mu$ in a solution containing $0.04 \% \mathrm{NH}_{4} \mathrm{OH}$. A Beckman DU spectrophotometer was employed for all enzymatic assays involving changes in absorbancy at a single wave length.

Enzyme assays. Formate-activating enzyme was assayed in leukocytes and erythrocytes by methods described previously $(23,24)$. Dihydrofolic reductase was assayed by an indirect method in which the tetrahydrofolate formed in reaction 1 was measured with excess formate-activating enzyme (10). A direct assay, which measures the disappearance of both TPNH and dihydrofolate by the decrease in absorbancy at $340 \mathrm{~m} \mu$, was used with more purified enzyme preparations (17, 25).

Measurement of amethoptcrin. Intracellular amethopterin, bound to leukocyte or erythrocyte protein, was measured by its ability to inhibit a purified dihydrofolic reductase from guinea pig liver (26). The leukocyte lysate was treated with $0.2 \mathrm{vol}$ of $15 \%$ trichloroacetic acid (TCA) to liberate the bound amethopterin, and the supernatant solution obtained after centrifugation was neutralized with 0.4 vol of Tris buffer, at $\mathrm{pH} 9.0$. A1ternatively, an erythrocyte lysate was treated in a similar manner with 0.4 vol of $15 \%$ TCA and $0.8 \mathrm{vol}$ of Tris buffer at $\mathrm{pH}$ 9.0. The amount of amethopterin present in the TCA-soluble fraction $(0.05$ to $0.5 \mathrm{ml})$ was determined by comparing the inhibition produced by the fraction on the standard dihydrofolic reductase system with that produced by graded amounts of amethopterin. As little as $10^{-6} \mu$ mole amethopterin can be detected by this method (27). The presence in the TCA extract of inhibitory materials other than amethopterin was rendered unlikely by the observation that leukocyte lysates from patients not treated with amethopterin caused no inhibition of the test system.

Separation of amethopterin from dihydrofolic reductase. In a typical experiment, $15 \mathrm{ml}$ of leukocyte lysate from a patient treated with amethopterin was mixed with $0.3 \mathrm{vol}$ of $2 \%$ protamine sulfate. After centrifugation at $10,000 \mathrm{~g}$ for 5 minutes, the precipitate was discarded, and the supernatant solution $(18 \mathrm{ml})$ was dialyzed overnight against $3 \mathrm{~L}$ of $0.005 \mathrm{M} \mathrm{KCl}$. Any precipitated protein was discarded after centrifugation, and the supernatant fluid $(19 \mathrm{ml})$ was applied to a $1.5 \times 12-\mathrm{cm}$ column of DEAE-cellulose previously washed with $1 \mathrm{~L}$ of $0.005 \mathrm{M}$ $\mathrm{KCl}$. Stepwise elution was then accomplished with 100$\mathrm{ml}$ portions of $0.005 \mathrm{M} \mathrm{KCl}, 0.15 \mathrm{M} \mathrm{KCl}$, and $0.5 \mathrm{M} \mathrm{KCl}$. Each of the three fractions was lyophilized to dryness, dissolved in $5 \mathrm{ml}$ of water, and assayed for enzyme and inhibitor. These data, presented in Table III, are discussed under Results.

Purification of erythrocyte dihydrofolic reductase. From $30 \mathrm{ml}$ of blood obtained from a patient undergoing amethopterin treatment, erythrocytes were separated by centrifugation, washed, and lysed as described above. One hundred $\mathrm{ml}$ of water, $33 \mathrm{ml}$ of ethanol, and $22 \mathrm{ml}$ of chloroform were added to the hemolysate $(50 \mathrm{ml})$. Each of the organic solvents was precooled to $-10^{\circ} \mathrm{C}$. The mixture was stirred vigorously for 1 minute, and after centrifugation in a glass container at $900 \mathrm{~g}$ for 10 minutes, the upper, pink layer was removed and dialyzed overnight against $4 \mathrm{~L}$ of distilled water (28). The dialyzed solution was then added to 0.5 vol of a DEAEcellulose suspension ( $80 \mathrm{mg}$ per $\mathrm{ml}$ ), the mixture was stirred for 10 minutes at $4^{\circ} \mathrm{C}$, centrifuged at $900 \mathrm{~g}$ for 10 minutes, and the unabsorbed fraction was discarded. The DEAE-cellulose was washed with three $20-\mathrm{ml}$ portions of $0.5 \mathrm{M} \mathrm{KCl}$, and the resultant eluant fractions were combined and lyophilized to dryness (29). The reddish powder was reconstituted with $5 \mathrm{ml}$ of $0.05 \mathrm{M}$ Tris buffer at $\mathrm{pH} 7.5$ and clarified by centrifugation at $10,000 \mathrm{~g}$ for 15 minutes. A tenfold purification of erythrocyte dihydrofolic reductase activity was achieved by this procedure.

\section{RESULTS}

Dihydrofolic reductase in leukocytes of leukemia patients during remission. During a previous study of leukocyte dihydrofolic reductase in patients with acute leukemia, it was noted that after amethopterin therapy there was a five- to twentyfold increase in the enzyme level per cell. This event also occurred in patients despite a concomitant decline in the total white cell count and

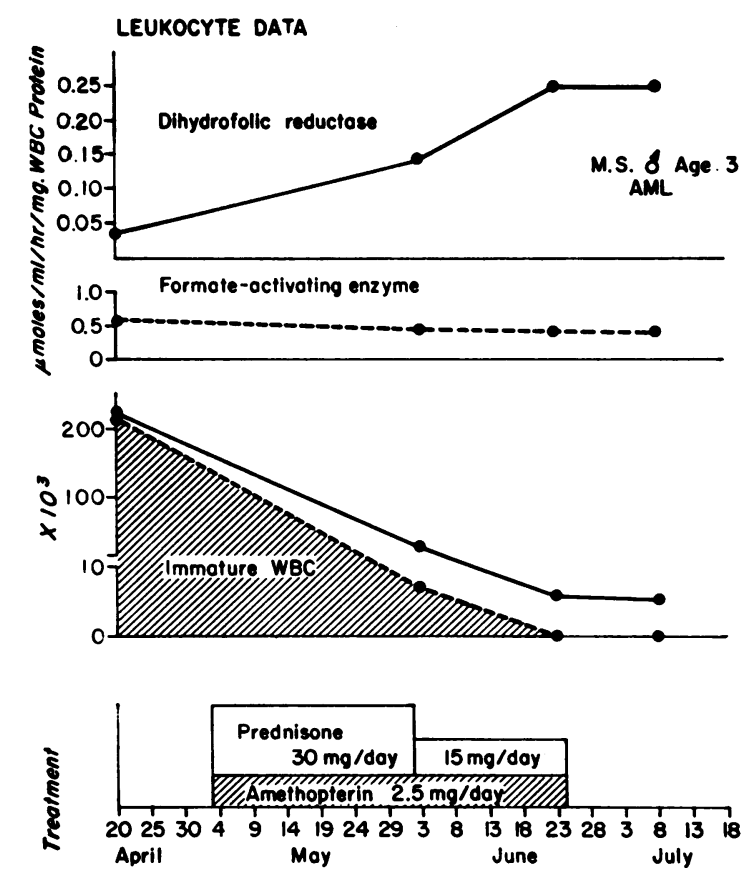

Fig. 1. Leukocyte dihydrofolic REductase AND FORMATE-ACtivating ENZYME IN A CHILD With ACUTE MYELOCYTIC LEUKEMIA UNDERGOING TREATMENT WITH AMETHOPTERIN AND PREDNISONE, AS INDICATED. 
TABLE I

Dihydrofolic reductase in leukocytes and erythrocytes of patients with nonhematologic neoplasms after amethopterin therapy

\begin{tabular}{|c|c|c|c|c|}
\hline \multirow[b]{2}{*}{ Patient } & \multirow[b]{2}{*}{ Diagnosis } & \multirow[b]{2}{*}{ Treatment } & \multicolumn{2}{|c|}{ Peak of dihydrofolic reductase activity* } \\
\hline & & & Erythrocytes & Leukocytes \\
\hline Group 1 & & Multiple doses of amethopterin & $\begin{array}{l}\text { Mmoles } / \mathrm{hr} / \mathrm{g} \\
\text { hemoglobin }\end{array}$ & $\underset{p \text { protein }}{\mu m o l e s / h r}$ \\
\hline & Choriocarcinoma & $\begin{array}{l}25 \mathrm{mg} \text { per day } \times 3 \\
25 \mathrm{mg} \text { per day } \times 6\end{array}$ & 11.0 & 0.45 \\
\hline V.M. & Anaplastic carcinoma & $\begin{array}{l}10 \mathrm{mg} \text { per day } \times 5 \\
3.75 \mathrm{mg} \text { per day } \times 7\end{array}$ & 14.0 & 0.22 \\
\hline R.T. & Carcinoma of rectum & $5 \mathrm{mg}$ per day $\times 21$ & 9.0 & 0.18 \\
\hline Group 2 & & Single dose of amethopterin & & \\
\hline $\begin{array}{l}\text { C.R. } \\
\text { C.M. } \\
\text { G.N. }\end{array}$ & $\begin{array}{l}\text { Carcinoma of colon } \\
\text { Carcinoma of stomach } \\
\text { Melanoma }\end{array}$ & $\begin{array}{l}20 \mathrm{mg} \\
20 \mathrm{mg} \\
20 \mathrm{mg}\end{array}$ & $\begin{array}{l}1.9 \\
1.1 \\
8.0\end{array}$ & $\begin{array}{l}0.07 \\
0.09 \\
0.20\end{array}$ \\
\hline Group 3 & & Folinic acid, folic acid, amethopterin & & \\
\hline $\begin{array}{l}\text { P.F. } \\
\text { A.K. } \\
\text { L.B. }\end{array}$ & $\begin{array}{l}\text { Refractory anemia } \\
\text { Folic acid deficiency } \\
\text { Adenomatosis of lung with } \\
\quad \text { metastasis }\end{array}$ & $\begin{array}{l}\text { Folinic acid, } 3 \mathrm{mg} \text { im per day } \times 7 \\
\text { Folic acid, } 15 \mathrm{mg} \text { per day } \times 7 \\
\text { Amethopterin, } 50 \mathrm{mg} \text { per day } \times 5 \text { intra- } \\
\text { arterially; folinic acid, } 12 \mathrm{mg} \text { im per } \\
\text { day } \times 5\end{array}$ & $\begin{array}{r}t \\
+ \\
4.6\end{array}$ & $\stackrel{\dagger}{\dagger}+{ }_{0}^{\dagger}$ \\
\hline
\end{tabular}

* All values represent the highest level of dihydrofolic reductase measured after amethopterin. Enzyme activity could not be detected in any of the subjects before amethopterin therapy.

$\dagger$ None detected.

in the percentage of immature forms. The data in Figure 1, which were obtained from a 3-year-old child with acute myelocytic leukemia who was undergoing treatment with amethopterin, illustrate this point. Approximately 50 days after amethopterin therapy was begun, a complete hematologic remission was achieved inasmuch as no abnormal cells were noted in the peripheral blood and the percentage of immature forms in the bone marrow was within normal limits. During this period of remission, however, approximately a fivefold increase occurred in the level of the leukocyte dihydrofolic reductase, whereas, in comparison, the level of a folic acid-dependent system, formateactivating enzyme, remained relatively constant. Although this patient was also receiving prednisone, ${ }^{6}$ the observed rise in the enzyme activity cannot be attributed to this agent, since it has been shown previously that when patients are treated with agents other than folic acid antagonists, there is no increase in reductase activity (19).

Dihydrofolic reductase in leukocytes and erythrocytes of amethopterin-treated patients with nonhematologic neoplasms. Since it appeared that even mature leukocytes could develop an increased level of this enzyme as a consequence of amethop-

\footnotetext{
${ }^{6} 17 \alpha, 21$-Dihydroxy-1,4-pregnadiene-3,11,20-trione.
}

terin treatment, studies were carried out on nonleukemic subjects. Table I gives information regarding the diagnosis, treatment of each patient, and "peak" dihydrofolic reductase activities. Initially, three patients comprising group 1 of Table I were studied before and after treatment with daily doses of amethopterin. Reductase activity was not detected in either the leukocytes or erythrocytes of any patient before therapy, but after amethopterin, enzyme activity appeared in both types of cells. Detailed data on the rate of appearance and level of this enzyme as well as similar data for the formate-activating enzyme in one of these patients, V.M., are presented in Figure $2, \mathrm{~A}$ and $\mathrm{B}$. Dihydrofolic reductase activity was first detected in the leukocytes and erythrocytes of this patient 5 days after amethopterin treatment was initiated, and higher levels of the enzyme were found 8 and 15 days after the start of therapy. Treatment with amethopterin was discontinued on day 15 , and thereafter the level of the leukocyte enzyme decreased rapidly, while a slower decline was noted for the erythrocyte enzyme. The increase in erythrocyte formate-activating enzyme seen in Figure 2 has been shown previously to be associated with reticulocytosis (24).

In group 2 of Table I, data are presented on 
three patients who received only a single infusion of $20 \mathrm{mg}$ of amethopterin, administered during 1 hour. Once again, measurable levels of dihydrofolic reductase appeared in both the leukocytes and erythrocytes of each patient. The detailed data for one of the patients, C.M., are presented in Figure 3, $\mathrm{A}$ and $\mathrm{B}$. Before treatment, there was no evidence of blood loss in this patient, and the following hematological measurements were normal : hematocrit, reticulocyte count, $\mathrm{Fe}^{59}$ plasma turnover, and red cell utilization of $\mathrm{Fe}^{59}$. After the intravenous infusion of $20 \mathrm{mg}$ of amethopterin, dihydrofolic reductase activity in the leukocytes reached a peak at about 9 days, but then decreased to a nondetectable level during the next 14 days. The leukocyte and differential counts did not vary appreciably during this period, and the leukocyte formate-activating enzyme was relatively constant. As shown in Figure $3 \mathrm{~B}$, the erythrocytes developed a measurable dihydrofolic reductase ac-
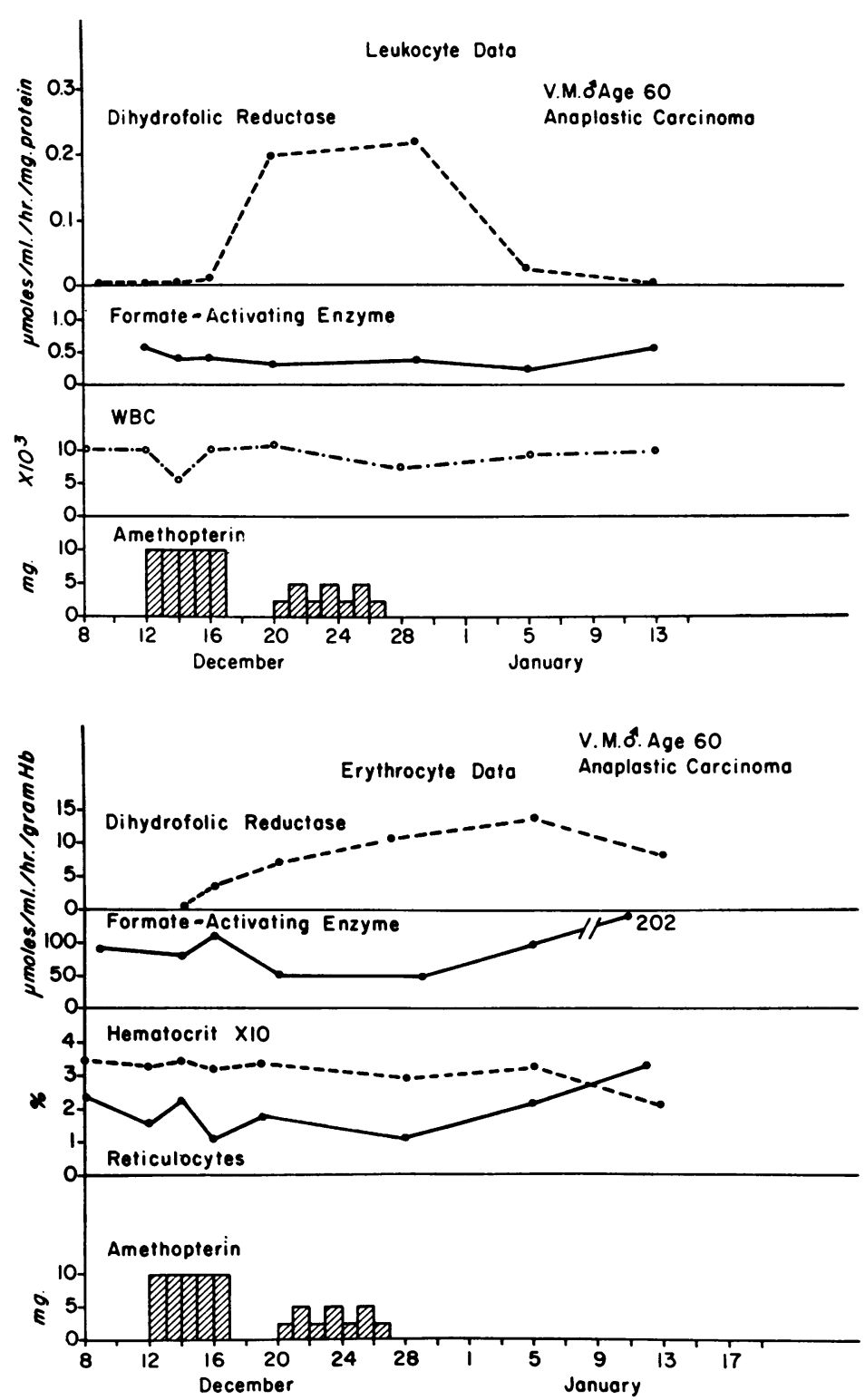

Fig. 2. Dihydrofolic Reductase and formate-ACtivating enzyMe in LEUKocytes (A) AND ERYthrocytes (B) OF A PATIENT (V.M.) With ANAPLASTIC CARCINOMA TREATED WITH AMETHOPTERIN. 

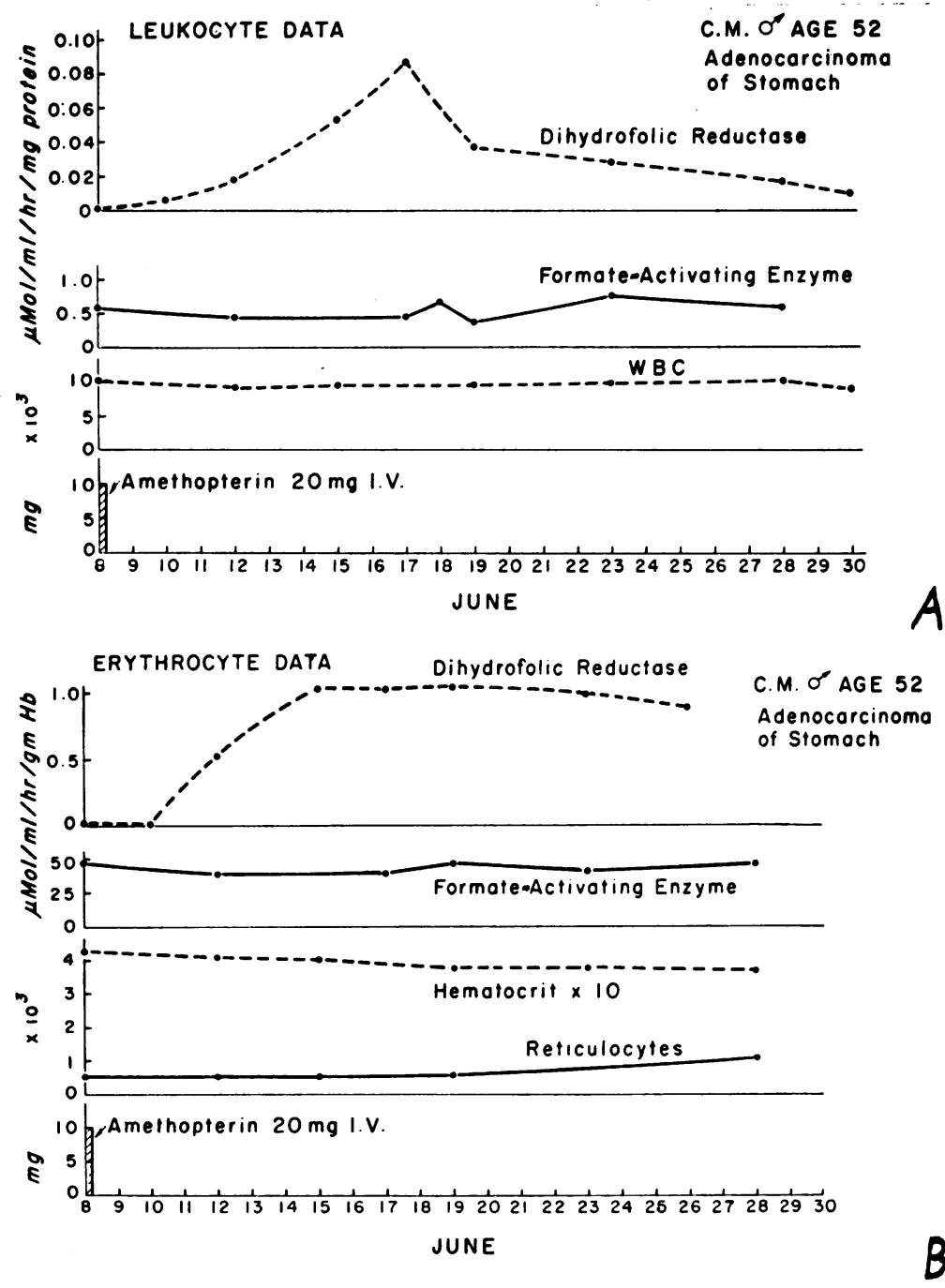

Fig. 3. LEUKOCYTE DIHYDROFOLIC REDUCTASE AND FORMATE-ACTIVATING ENZYME IN THE LEUKOCYTES (A) AND ERYTHROCYTES (B) AFTER INTRAVENOUS INFUSION OF 20 Mg OF AMETHOPTERIN IN A PATIENT (C.M.) WITH ADENOCARCINOMA OF THE STOMACH.

tivity 4 days after amethopterin, and the maximal level, reached in 8 days, persisted throughout the next 15 days. Although not shown in Figure $3 \mathrm{~B}$, the erythrocyte reductase level had still not declined appreciably on day 48 after amethopterin.

The other two patients in group 2, C.R. and G.N., showed similar responses, although the latter, with an advanced melanoma associated with marked anemia and a hyperplastic erythroid marrow, had an exaggerated response. In addition to a single infusion of amethopterin, this patient was given $150 \mathrm{mg}$ of 6-mercaptopurine each day, and a reticulocytosis and a mild leukocytosis oc- curred during the second week of treatment. Leukocyte dihydrofolic reductase in this patient, at day 10 , rose to a peak level two to three times higher than that of the other patients in group 2, while the erythrocyte enzyme increased to a level four times higher.

The data for the first two patients, P.D. and A.K., in group 3, in which folic or folinic acids ${ }^{7}$ were administered instead of amethopterin, indicated that the appearance and subsequent increase

${ }^{7} N-\{p-[$ ( 2-Amino-4-hydroxypyrimido [4,5-6]pyrazin-6yl-methyl)-amino]-benzoyl\}-glutamic acid and 5-formyl5,6,7,8-tetrahydropteroyl-L-glutamic acid. 
in dihydrofolic reductase is evoked only by the enzyme inhibitor amethopterin, and is not caused by normal folic acid compounds. On the other hand, as shown by the third patient, L.B., in this group, the simultaneous administration of amethopterin and folinic acid did not prevent the appearance of the enzyme in peripheral blood cells.

Properties of the induced erythrocyte and leukocyte dihydrofolic reductase from nonleukemic patients. After induction of the enzyme by amethopterin, dihydrofolic reductase was partially purified from both the leukocytes and erythrocytes of nonleukemic patients. For the enzymes from both cells, the principal $\mathrm{pH}$ optimum occurred at 8.0 to 8.5 , with a small optimum (about one-third the activity) at $\mathrm{pH}$ 5.0. The enzymes were specific for TPNH, although at $\mathrm{pH} 5.0$ a small amount of activity was observed with DPNH. The induced erythrocyte and leukocyte enzymes are inhibited by very low levels of amethopterin, as shown by the data in Table II. All of these results support the assumption that the amethopterininduced enzyme in leukocytes or erythrocytes has the same properties as the previously described enzyme from leukemic leukocytes (10).

Effect of a single dose of amethopterin on patients with chronic leukemia. Following the above observation that single doses of amethopterin stim-
TABLE II

Inhibition of induced erythrocyte and leukocyte dihydrofolic reductase by amethopterin

\begin{tabular}{|c|c|c|}
\hline Enzyme source & $\begin{array}{l}\text { Concentration of } \\
\text { amethopterin }\end{array}$ & $\begin{array}{l}\text { Enzyme } \\
\text { activity* }\end{array}$ \\
\hline & $M$ & $\underset{\text { protein }}{\mu \text { moles } / \mathrm{hr} / \mathrm{mg}}$ \\
\hline Erythrocyte & $\begin{array}{c}1 \times 10^{-8} \\
1 \times 10^{-7}\end{array}$ & $\begin{array}{l}0.033 \\
0.022 \\
0.001\end{array}$ \\
\hline Leukocyte & $\begin{array}{c}0 \\
1 \times 10^{-8} \\
1 \times 10^{-7}\end{array}$ & $\begin{array}{l}0.046 \\
0.031 \\
0.008\end{array}$ \\
\hline
\end{tabular}

* Measured by indirect assay as described in Materials and Methods.

ulated the transient appearance of dihydrofolic reductase in blood cells of nonleukemic patients, the nature of this response in patients with chronic leukemia was investigated. Data obtained from the leukocytes of a patient, S.B., with chronic lymphocytic leukemia, are presented in Figure 4. No dihydrofolic reductase was found in the leukocytes of this patient before treatment, although barely detectable levels of the enzyme have been encountered previously in some patients with this disease (23). Although reductase activity was stimulated in this patient by amethopterin, the peak level was lower than that observed in the three patients with nonhematologic diseases who
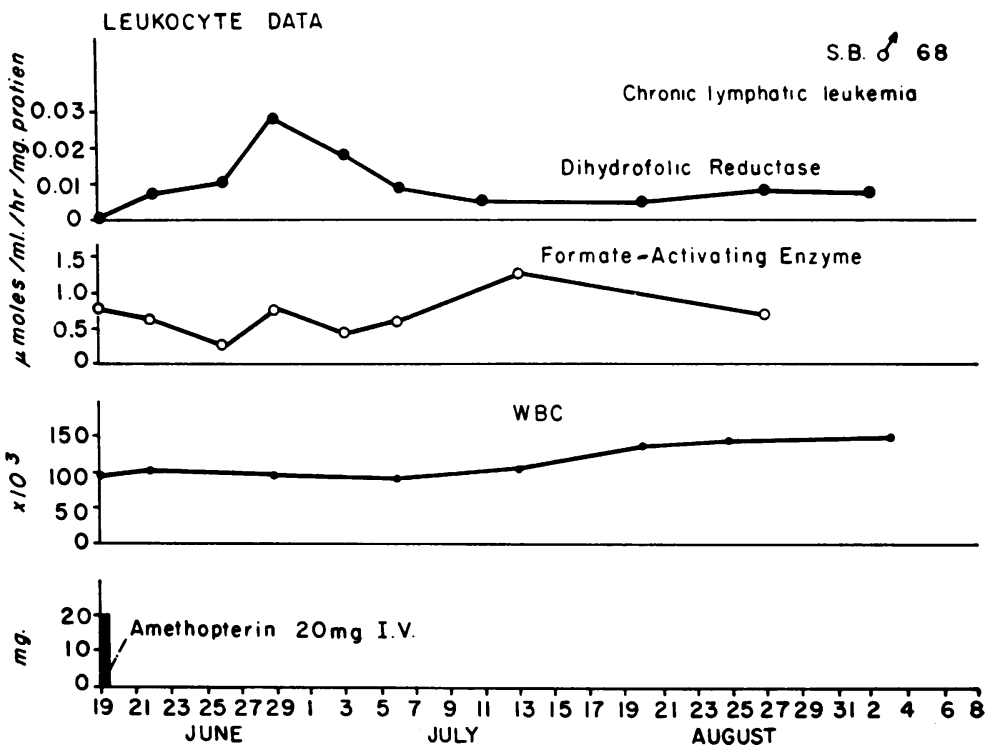

Fig. 4. LEUKOCYTE DIHYDROFOLIC REDUCTASE AND FORMATE-ACTIVATING ENZYME AFTER INTRAVENOUS INFUSION OF 20 MG OF AMETHOPTERIN IN A PATIENT (S.B.) WITH CHRONIC LYMPHOCYTIC LEUKEMIA. 


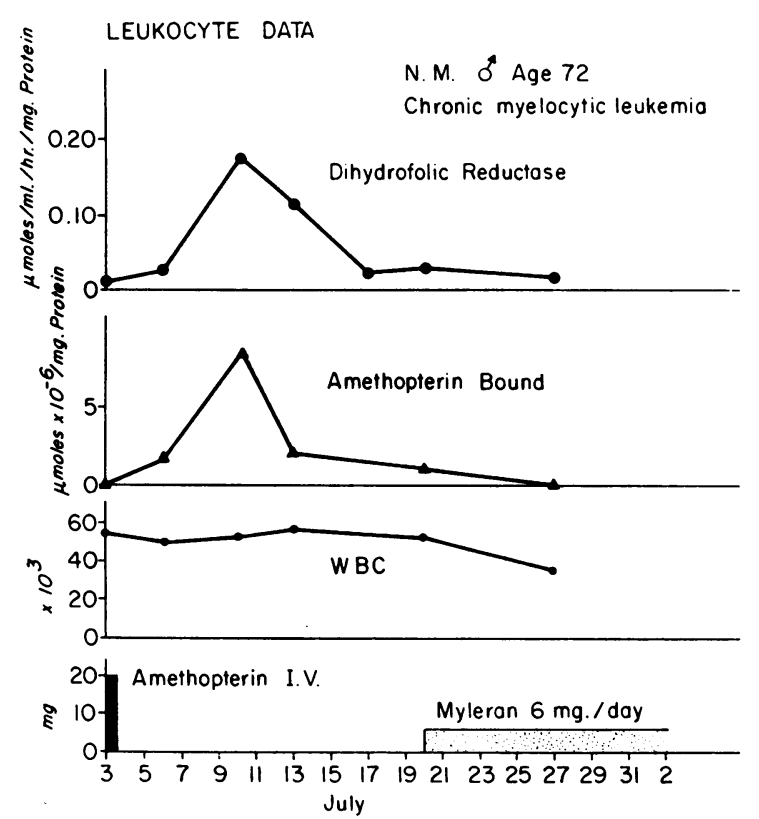

FIg. 5. LEUKOCYTE DIHYDROFOLIC REDUCTASE AND AMOUNT OF INHIBITOR PRESENT PER MILLIGRAM OF LEUKOCYTE PROTEIN AFTER INTRAVENOUS INFUSION OF 20 MG OF AMETHOPTERIN IN A PATIENT (N.M.) WITH CHRONIC MYELOCYTIC LEUKEMIA.

had also received a single dose of amethopterin (compare group 2, Table I). Furthermore, there was a slower decrease in reductase activity, and activity was still measurable 43 days after amethopterin. During the experimental period, there was no decrease in the leukocyte count or change in the differential count, which consisted of over $90 \%$ mature lymphocytes.

Data from a patient, N.M., with chronic myelocytic leukemia who was treated with a single dose of amethopterin are presented in Figure 5. As in other patients with untreated chronic myelocytic leukemia, a measurable level of leukocyte dihydrofolic reductase was present before amethopterin. After a single dose, the activity increased rapidly and after 7 days reached a peak value more than 10 times greater than the pretreatment level. The amount of amethopterin present in the leukocytes was determined (see Figure 5). The appearance and subsequent rise of intracellular inhibitor closely paralleled the rise in dihydrofolic reductase activity. As in the preceding patient, the leukocyte count and differential count in this patient remained relatively constant after amethopterin.

Reactivation of inhibited leukocyte dihydrofolic reductase. Since it has been shown above that amethopterin is present in the leukocytes of the chronic myelocytic leukemia patient N.M. after treatment, it was of interest to attempt the reactivation of any enzyme in the inhibited state. On day 10 after amethopterin, leukocytes were isolated from $100 \mathrm{ml}$ of this patient's blood, and the lysate from these cells was treated according to the chromatographic procedure for the purification of dihydrofolic reductase. As shown in Table III, dialysis did not dissociate the enzyme-inhibitor complex. After chromatography, however, all of the enzyme activity was found in the $0.15 \mathrm{M} \mathrm{KCl}$ fraction. The data in Table III show that the total units of enzyme activity had almost doubled after the chromatographic step, indicating that a considerable amount of inhibited enzyme had been reactivated.

Number of molecules of amethopterin per leukocyte and total amethopterin content of the circulating leukocytes. In the preceding experiment, the data on the number of leukocytes, the milligrams of soluble protein per leukocyte, and the amethopterin content of the extract can be used to calculate the amount of amethopterin present in each leukocyte. Since the amount of amethopterin found per milligram of cellular protein on day 7 was $8 \times 10^{-6} \mu$ moles and $50 \mathrm{mg}$ of protein was released per $10^{9}$ leukocytes lysed, the amount of amethopterin per cell is approximately $4 \times 10^{-19}$ moles. This calculation assumes that the inhibitor is distributed uniformly among the various cells at the time of analysis, i.e., on day 7 after amethopterin. If the $100 \mathrm{ml}$ of blood, from which $4 \times 10^{9}$ leukocytes were obtained, is assumed to represent $2 \%$ of the total circulating leukocytes, then the total amount of amethopterin present in all of the circulating leukocytes on this day would be $0.08 \mu$ mole, or approximately 0.04

TABLE III

Separation of amethopterin from dihydrofolic reductase

\begin{tabular}{lcc}
\hline Fraction & \multicolumn{1}{c}{$\begin{array}{c}\text { Total } \\
\text { inhibitor }\end{array}$} & $\begin{array}{c}\text { Total } \\
\text { dihydrofolic } \\
\text { reductase } \\
\text { activity }\end{array}$ \\
\hline Crude extract & $1.6 \times 10^{-4}$ & $\mu m o l e s / h r$ \\
Dialysate & $1.4 \times 10^{-4}$ & 18.0 \\
$0.005 \mathrm{M} \mathrm{KCl}$ & None detected & 15.6 \\
$0.15 \mathrm{M} \mathrm{KCl}$ & None detected & 0 \\
$0.5 \mathrm{M} \mathrm{KCl}$ & $1.1 \times 10^{-4}$ & 29.0 \\
& & 1.0 \\
\hline
\end{tabular}


mg. This represents approximately $0.20 \%$ of the administered dose.

\section{DISCUSSION}

The key role of the folic acid coenzyme tetrahydrofolate in the synthesis of inosinate, thymidylate, histidine, and methionine is now well established $(4,30-32)$. Inhibition of dihydrofolic reductase by amethopterin prevents the synthesis of tetrahydrofolate, thereby interfering with each of the biosynthetic reactions above.

The rise in dihydrofolic reductase activity observed in bacteria and mouse leukemia cells after exposure to antifolic agents has been attributed to the selective survival of those cells having a higher initial level of enzyme (11-17). Several findings in the present study indicate that the mechanism for increased dihydrofolic reductase in leukocytes and erythrocytes of patients after amethopterin treatment is not cell selection, but that enzyme "induction" s actually occurs. The first of these findings is that a single, relatively nontoxic dose of amethopterin results in the rise of dihydrofolic reductase, and the prolonged administration of an agent usually essential for the selection of resistant cell population is not necessary. Second, the time course of the rise in dihydrofolic reductase level is more in keeping with enzyme induction than with cell selection. Thus, the enzyme level rises to a peak from 9 to 14 days after amethopterin and then declines, in contrast with the prolonged plateau of high activity found in the other systems when amethopterin administration is stopped. The time sequence of the rise and fall of the enzyme activity in the leukocytes of nonleukemic patients bears a great resemblance to the curves describing granulocyte life-span obtained with tritiated thymidine. $\mathrm{P}^{32}$, and $\mathrm{DFP}^{32}$ (diisopropylfluorophosphate) (33-36). Likewise, in the single subject with chronic lymphocytic leukemia who was investigated, the slower decline of amethopterin-induced dihydrofolic reductase activity parallels the longer life-span reported for mature lymphocytes. Similarly, the curve of erythrocyte dihydrofolic reductase induced by amethopterin closely approximates the

\footnotetext{
8 Enzyme "induction" is used here to mean an increase in dihydrofolic reductase activity in response to the stimulus of amethopterin.
}

erythrocyte-labeling curve obtained after the administration in vivo of $\mathrm{Fe}^{59}$ (37). It thus appears that the rise in enzyme activity persists for only one generation of hematopoietic cells and is not passed on to successive generations, as would be expected if there were cell selection with a stable mutational change.

The strongest evidence in favor of enzyme induction is perhaps the demonstration that the presence, rise, and fall of the inhibitor in the leukocyte closely parallels the level of the enzyme (Figure 5). This is in keeping with the concept (38) that the presence of inducer in the cell is essential for enzyme induction.

In light of the present findings, the following mechanism is tentatively proposed to explain the rise observed in dihydrofolic reductase activity in leukocytes and erythrocytes after amethopterin treatment. Amethopterin is taken up by dividing cells in the bone marrow and to some degree inhibits the existing intracellular dihydrofolic reductase. In these cells that do not take up lethal amounts of amethopterin, the partial metabolic block results in a reduced amount of tetrahydrofolate, which in turn causes a reduction in the synthesis of some key metabolite (e.g., a pyrimidine, purine, or amino acid) necessary for further cell division. If this metabolite acts, moreover, as a repressor in the synthesis of dihydrofolic reductase. a decreased amount of the metabolite would cause an increased synthesis of the enzyme. Thus, the net effect of this chain of events would be to overcome the original amethopterin block, and the resulting increased level of reductase would then persist during the life span of each cell. The properties of such an induced enzyme should be similar in all respects to those of the original enzyme (19), as the present study shows is the case. A somewhat analogous mechanism has been postulated to explain the inhibition of histidine synthesis that occurs when bacteria are treated with the histidine analogue thiazolealanine (39). An alternative explanation for the observed rise is also possible, i.e., this is enzyme induction in the sense that the amethopterin acts as a substrate for dihydrofolic reductase (folic acid or dihydrofolic acid) and not by a derepression mechanism. This interpretation is less appealing, since folic acid administration did not result in increased enzyme activity, but inasmuch as analogues can be better 
enzyme inducers than substrates, this possibility cannot be discounted.

The relation of the present findings to the resistance acquired by leukemia patients to amethopterin is not yet clear. The leukemic leukocyte from patients with acute leukemia maintains its ability to reproduce, but does not differentiate and may have a long life-span (40). Thus, a high level of dihydrofolic reductase induced by nonlethal amounts of amethopterin should afford protection to the cell against subsequent doses of amethopterin. The situation is obviously more complicated, however, for if the increased level of dihydrofolic reductase were the only factor in the mechanism of resistance, patients who had become resistant to amethopterin presumably could be treated with other drugs pending the return of sensitivity to the antifolic agents. The recovery of sensitivity would be predicted by the present studies, since the enzyme level in the leukocyte returns to its pretreatment value when antifolic therapy is discontinued. In addition, there appears to be a limit to which the level of dihydrofolic reductase activity can rise, since subjects with choriocarcinoma or leukemia who are treated with maximal amounts of amethopterin do not develop levels greater than $0.7 \mu$ mole per hour per mg protein. An acquired impermeability of the cells to folic acid antagonists during amethopterin resistance has not yet been assessed adequately in human leukemia and may prove to be an additional factor. A better understanding of possible control mechanisms involved in the biosynthesis of the protein dihydrofolic reductase and the manner of transport in the body of the folic acid antagonists might result in a more effective regimen for selection and treatment of leukemia patients with the currently used antifolic agents.

\section{SUMMARY}

After administration of amethopterin, the appearance of measurable levels of dihydrofolic reductase has been observed in the leukocytes of seven patients with nonhematologic diseases. In five patients (three with nonhematologic neoplasms, one with chronic myelocytic leukemia, and one with chronic lymphocytic leukemia), a single 20-mg infusion of amethopterin was given. In all instances, dihydrofolic reductase activity appeared in the leukocytes and erythrocytes within
1 week. In the subject with chronic myelocytic leukemia, a tenfold rise over the pretreatment value occurred in the level of the enzyme.

Studies of the induced enzyme from the leukocytes of the nonhematologic patients showed that the kinetic properties, including inhibition by amethopterin, were similar to those reported previously for the enzyme isolated from leukemic leukocytes. In leukocytes from a patient with chronic myelocytic leukemia treated with amethopterin, the accumulation of inhibitor paralleled the increase in dihydrofolic reductase activity. These observations suggest that the mechanism of reductase inhibition involves the uptake of amethopterin by immature cells, inhibition of dihydrofolic reductase activity, and a resultant decrease in the formation of tetrahydrofolate. This sequence could lead to a decreased synthesis of some metabolite that ordinarily represses the synthesis of dihydrofolic reductase. Thus, the enzyme level ultimately rises and remains elevated during the life-span of the cell.

\section{ACKNOWLEDGMENTS}

The authors are indebted to Mrs. Margaret Albrecht and Mrs. Aline Alenty for their technical assistance and to Drs. C. A. Finch, D. H. Coleman, Q. B. DeMarsh, J. Hartmann, M. Origenes, and J. R. Czajkowski for their cooperation in this program.

\section{REFERENCES}

1. Bertino, J. R., B. M. Simmons, and D. M. Donohue. Studies on the mechanism of resistance to the folic acid antagonists. Clin. Res. 1961, 9, 157.

2. Zakrzewski, S. F., and C. A. Nichol. Evidence for a single enzyme reducing folate and dihydrofolate. J. biol. Chem. 1960, 235, 2984.

3. Mathews, C. Enzymatic interconversions of folic acid, dihydrofolic acid and tetrahydrofolic acid. Ph.D. thesis, Seattle, University of Washington, 1962.

4. Wahbe, A. J., and M. Friedkin. Direct spectrophotometric evidence for the oxidation of tetrahydrofolate during the enzymatic synthesis of thymidylate. J. biol. Chem. 1961, 236, PC11.

5. Huennekens, F. M., and M. J. Osborn, Folic acid coenzymes and one-carbon metabolism. Advanc. Enzymol. 1959, 21, 369.

6. Nichol, C. A., and A. D. Welch. On the mechanism of action of aminopterin. Proc. Soc. exp. Biol. (N. Y.) 1950, 74, 403.

7. Futterman, S., and M. Silverman. The "inactivation" of folic acid by liver. J. biol. Chem. 1957, 225, 31 .

8. Osborn, M. J., M. Freeman, and F. M. Huennekens. Inhibition of dihydrofolic reductase by aminop- 
terin and amethopterin. Proc. Soc. exp. Biol. (N. Y.) 1958, 97, 429.

9. Zakrzewski, S. F., and C. A. Nichol. On the enzymic reduction of folic acid by a purified hydrogenase. Biochim. Biophys. Acta (Amst.) 1958, 27, 425.

10. Bertino, J. R., B. W. Gabrio, and F. M. Huennekens. Dihydrofolic reductase in human leukemic leukocytes. Biochem. biophys. Res. Commun. 1960, 3, 461.

11. Broquist, H. P.. R. A. Kohler, D. J. Hutchinson, and J. H. Burchenal. Studies on the enzymatic formation of citrovorum factor by Streptococcus faecalis. J. biol. Chem. 1953, 202, 59.

12. Nichol, C. A., S. F. Zakrzewski, and A. D. Welch. Resistance to folic acid analogues in a strain of Streptococius faccalis. Proc. Soc. exp. Biol. (N. Y.) $1953,83,272$.

13. Nichol, C. A. Studies on resistance to folic acid antagonists in The Leukemias, J. W. Rebuck, F. H. Bethell, and R. IV. Monto, Eds. New York, Academic Press, 1957, p. 583.

14. Anton, A. H., and C. A. Nichol. Studies on the nature of resistance of Streptococcus faecalis to folic acid antagonists. Biochem. Pharmacol. 1960, 3, 1.

15. Fischer, G. A. Increased levels of folic acid reductase as a mechanism of resistance to amethopterin in leukemic cells. Biochem. Pharmacol. 1961, 7, 75.

16. Hakala, M. T., S. F. Zakrzewski, and C. A. Nichol. Relation of folic acid reductase to amethopterin resistance in cultured mammalian cells. J. biol. Chem. 1961, 236, 952.

17. Misra, D. K., S. R. Humphreys, M. Friedkin, A. Goldin, and E. J. Crawford. Increased dihydrofolic reductase activity as a possible basis of drug resistance in leukaemia. Nature 1961, 189, 39.

18. Bertino, J. R., B. W. Gabrio, and F. M. Huennekens. Increased activity of leukocyte dihydrofolic reductase in amethopterin-treated patients. Clin. Res. 1961, 9, 103.

19. Bertino, J. R., D. R. Donohue, B. W. Gabrio, R. Silber, A. Alenty, M. Meyer, and F. M. Huennekens. Increased level of dihydrofolic reductase in leukocytes of patients treated with amethopterin. Nature 1962, 193, 140.

20. Sober, H. A., F. J. Gotter, M. M. Wyckoff, and E. A. Peterson. Chromatography of proteins. II. Fractionation of serum protein on anion-exchange cellulose. J. Amer. chem. Soc. 1956, 78, 756.

21. Futterman, S. Enzymatic reduction of folic acid and dihydrofolic acid to tetrahydrofolic acid. J. biol. Chem. 1957, 228, 1031.

22. Blakley, R. L. Crystalline dihydropteroylglutamic acid. Nature (Lond.) 1960, 188, 231.

23. Bertino, J. R., R. S. Silber, M. Freeman, A. Alenty, M. Albrecht, B. W. Gabrio, and F. M. Huennekens. Studies on normal and leukemic leukocytes. IV. Tetrahydrofolate-dependent enzyme systems and dihydrofolic reductase. Submitted for publication.
24. Bertino, J. R., B. Simmons, and D. M. Donohue. Purification and properties of the formate-activating enzyme from erythrocytes. J. biol. Chem. 1962, 237, 1314.

25. Osborn, M. J., and F. M. Huennekens. Enzymatic reduction of dihydrofolic acid. J. biol. Chem. 1958, 233, 969.

26. Bertino, J. R., B. Simmons, and D. Donohue. Distribution and properties of the formate-activating enzyme in guinea pig tissue. Fed. Proc. 1962, 21, 476a.

27. Bertino, J. R., and G. A. Fischer. Techniques for the study of resistance to the folic acid antagonists. Meth. med. Res. 1963, 11, in press.

28. Huennekens, F. M., R. W. Caffrey, R. E. Basford, and B. W. Gabrio. Erythrocyte metabolism. IV. Its isolation and properties of methemoglobin reductase. J. biol. Chem. 1957, 227, 261.

29. Hennessey, M. A., A. M. Waltersdorph, F. M. Huennekens, and B. W. Gabrio. Erythrocyte metabolism. VI. Separation of erythrocyte enzymes from hemoglobin. J. clin. Invest. 1962, 41, 1257.

30. Buchanan, J. M., and S. C. Hartman. Enzymic reactions in the synthesis of purines. Advanc. Enzymol. 1959, 21, 199.

31. Huennekens, F. M., M. J. Osborn, and H. R. Whiteley. Folic acid coenzymes. Science 1958, 128, 120.

32. Rabinowitz, J. C. Folic ecid coenzymes in The Enzymes, 2nd ed., P. D. Boyer, H. Lardy, and K. Myrback, Eds. New York, Academic Press, 1960, vol. 2, p. 185.

33. Bond, V. P. in Kinetics of Cellular Proliferation, F. R. Stohlman, Ed. New York, Grune \& Stratton, 1960. p. 190.

34. Ottesen, J. On the age of human white cells in peripheral blood. Acta physiol. scand. 1954, 32, 75.

35. Cartwright, G. E., F. Stohlman, K. E. Fichtelius, D. L. Kline, L. G. Lajtha, S. Perry, E. P. Cronkite, L. S. Kelly, L. D. Hamilton, and E. E. Osgood. Discussion of leukocyte production and survival using $\mathrm{C}^{14}$ and $\mathrm{P}^{32}$ in The Kinetics of Cellular Proliferation, F. R. Stohlman, Ed. New York, Grune \& Stratton, 1959, p. 183.

36. Craddock, C. G., S. Perry, and J. S. Lawrence. Control of the steady state proliferation of leukocytes in The Kinetics of Cellular Proliferation, F. R. Stohlman, Ed. New York, Grune \& Stratton, 1959, p. 242.

37. Huff, R. L. Erythrocyte formation estimated by radioiron. Meth. med. Res. 1960, 8, 25.

38. Pollock, M. R. in The Enzymes, 2nd ed., P. D. Boyer, H. Lardy, and K. Myrback, Eds. New York, Academic Press, 1959, vol. 1, p. 619.

39. Moyed, H. S. Interference with the feed-back control of histidine biosynthesis. J. biol. Chem. 1961, 236, 2261.

40. Craddock, C. G., and G. S. Nakai. Leukemic cell proliferation as determined by an in vitro deoxyribonucleic acid synthesis. J. clin. Invest. 1962, 41,360 . 